\title{
A[N] ABSENT SPACE: 1355
}

\author{
Suha Hasan
}


It is 1979. Palestinian artist Mona Hatoum creates a kinetic sculpture, entitled Self-Erasing Drawing. The sculpture that was reproduced in 1994 and 2004 as + and - contains sand held within a circular plate, with a rotating mechanical arm, smooth on one side and jagged on the other. As one half of the arm rotates smoothing the sand, the other half disrupts it; or as one half builds patterns on the sand, the other devours it, depending on your vantage point. Within Mona's work is a juxtaposition of opposing forces that need to coexist. Absence is shaped by presence, and presence is shaped by absence - both meeting at a liminal point before one replaces the other.

This chapter occupies that liminal space of erasures, where absences are revealed and presences are obscured in a cyclic manner, and uses this liminal space as a means to reflect on and expose challenges facing discourse on Modern architecture heritage in the Gulf. Modern is deliberately spelled with a capital $M$ to describe Modernity as a political project and contested term within this chapter. The discourse on the Gulf is one that has yet to reconcile with an obfuscated past, a discourse lost in terminologies and translations of various forms, a discourse that ought to transcend national boundaries. The chapter unravels some of the issues pertaining to these challenges through consideration of the temporal evolution of a space within the Customs House (now operating as the Manama Post Office), a newly conserved building in the capital of Bahrain.

A venture into the literature of urban development in the Gulf reveals a fascination with quick urbanization reflected in the rise of towers and the rapid, inconsistent planning over the years among other connected issues. Previously, researchers have fallen into the tendency of labelling such developments and related issues with Gulf exceptionalism, arguing that the presence of these conditions are specific to the Gulf and cannot be found elsewhere. More recently this has been counter-argued in an attempt to shift the discourse of Gulf exceptionalism towards one that relates to transnational processes. ${ }^{1}$ There have been new approaches to the architecture conversation that attempt to go beyond political and geographical imaginations of the Gulf region to include both Arab and Iranian coasts of the Gulf and to extend further into the Indian Ocean. ${ }^{2}$ Simultaneously, there have been studies that look into the specificities of Gulf cities, comparing similarities yet also highlighting nuances and differences in how these cities have evolved. ${ }^{3}$ Occasionally within these studies, specifically when conducted by researchers with personal connections to the context, a nostalgic undertone and longing for a 'better' past can be detected. ${ }^{4}$ This emerging scholarly body of work reconnects discourse of the Gulf to global processes and enables a better understanding of the 


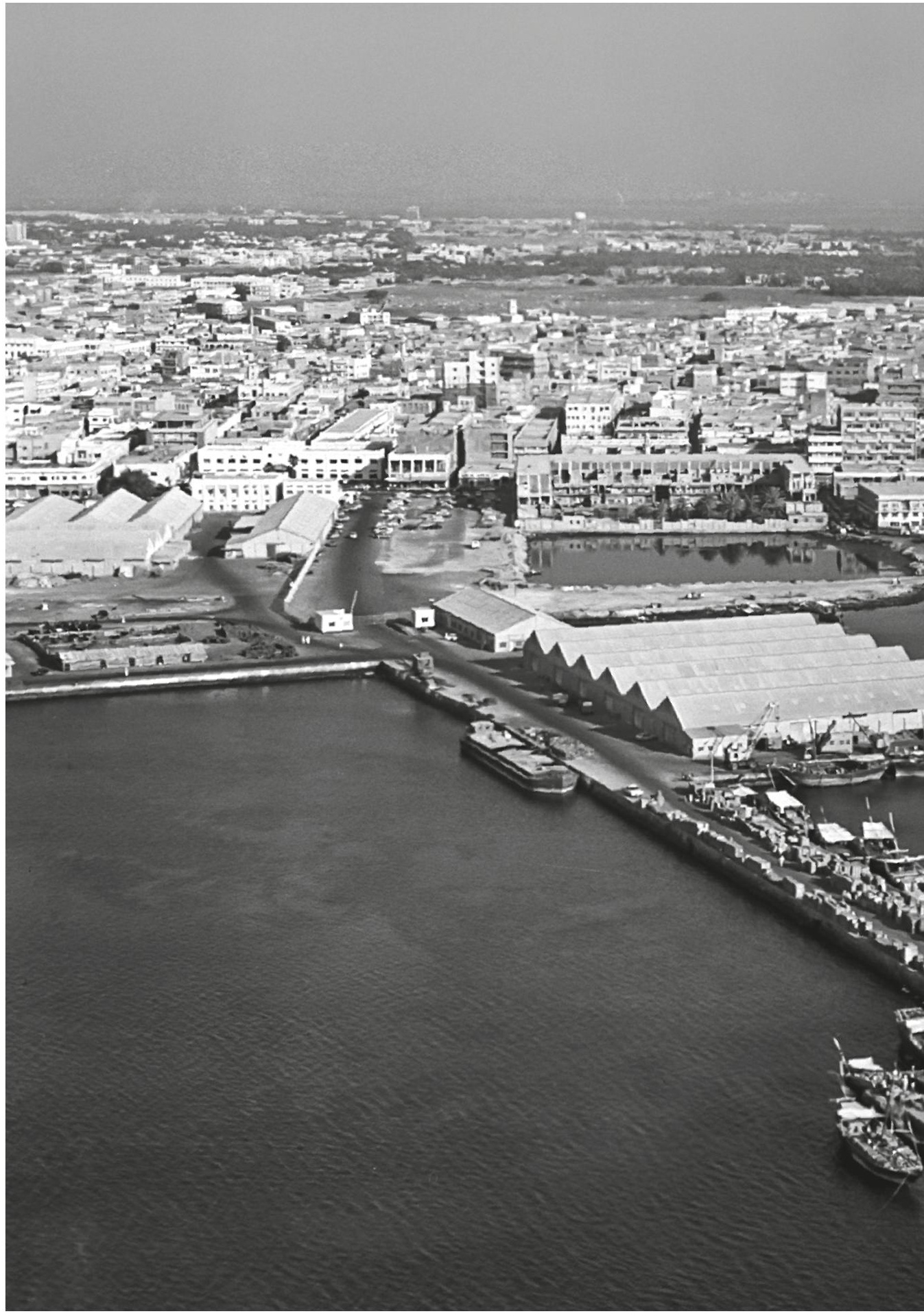

fig.1 Customs House, sheds, and pier in 1963 (Photo: Abdulla Al-Khan. Source: Bahrain House of Photography. Reuse not permitted). 
conditions found within the region while deconstructing the myth of exceptionalism. However, studies of and writing on architecture of Arab Gulf countries still, for the most part, dwell on the starting point of the discovery of oil, as if prior to the year 1931, when oil was discovered in Bahrain, the area was a barren land, devoid of civilization.

This is partly due to narratives of progress being intertwined with narratives of oil. Such narratives have been propagated by both the state and oil companies to legitimize its governance and their presence, respectively. A common challenge faced by researchers of the Gulf region relates to the lack of documentation or the deliberate obscuring of information as narratives of history continue to shift and change over time. ${ }^{5}$ This has perhaps contributed to the creation of this rupture within Gulf history, challenging the emergence of any discourse that attempts to draw from the past to address the future - as conveyed by the question posed by the editors of this book, "What future can be envisioned for the Gulf modernist [sic] heritage?". ${ }^{6}$ It is vital to understand the future as a temporality strongly connected to the past, for the further we can delve into the past, the more possible it becomes to identify future trajectories of Modern heritage. This longue durée approach to history is a means of understanding that widens the temporal scope of study to enable deeper attention to the slow unravelling of historical events that construct present conditions. ${ }^{7}$

The following is an attempt to provide a close reading of the formation of the 'Gulf Modernist city' through an inverted lens of an absent space within the Customs House. The project destabilizes concepts of time and Modern heritage through its practices of demolition, resurrection, and until recently an unrealized design. Therefore, Modern heritage as a concept is addressed critically through this project. Ann Laura Stoler elaborates on what she defines as conceptual habits, acknowledging the need for concepts as organizing guides, yet warns of both the epistemological and ontological violence that such a stability would entail. Following her line of argument of looking beyond conceptual habits, that consequently result in destabilizing and activating concepts, leads to a different understanding of Modern heritage and enables linking it to ambiguous colonial conditions. Stoler explains that such readings can enable perversion of unclear colonial conditions linked to temporalities that share common conditions to that of imperialism - that are as operative in Victorian India as in the periphery of the empire and its protectorates, in military bases today, and equally in intimate relations where one is vulnerable. ${ }^{8}$

The aim is to embark on an excavation in search of an absent space hidden in between what is visible and highlight the agency of that space within urban history. The invisible is interesting not only because it provokes many questions but also because it can potentially provide us with alternatives and opportunities 
long discarded. This chapter is a response to the broader topic of this book, and it denotes a tension in the process of the production of the built environment. The following research utilizes various archives but eschews the nostalgia, or at least attempts to, usually associated with unearthing the past and using archival material.

\section{Somewhere between 1936 and 1937: \\ A failure of interpretations}

This chapter can make many contradicting claims about the start of Bahrain's Modernity. The first claim is that Modernity started in 1931 when oil was discovered, leading to Bahrain's inclusion in the global network and providing resources for the industrial infrastructure of Modernity. The second claim is that Modernity of Bahrain started with the inclusion of its port in the global network in 1869, when Manama was incorporated into the shipping route of the British India Steam Navigation Company. ${ }^{9}$ On further reflection, another claim can be made that it goes back to 1783 when Ahmed ibn Muhammad Al-Khalifa also known as Ahmed Al-Fateh (the conqueror) arrived in Bahrain - a state narrative of the beginning of the story of Modernity in Bahrain, as displayed at the National Charter Monument. The final claim is to go 'forward', to understand Modern Bahrain, to Wednesday, March 31, 1926, when British administrator Charles Belgrave arrived at Manama's coastline by boat from Bushehr in Iran to resume his duties as advisor to the ruler, arguably soon to become one of the most influential (and controversial) individuals and historians - by virtue of his diary - in the history of Bahrain. ${ }^{10}$ There are many dates that can be chosen, from which a story of the Modern city can be netted out, subsequently from which a story of progress can be fabricated.

Bruno Latour challenges such a determination of a Modern era that breaks away from the past in his book We Have Never Been Modern. Although it does appear as if he addresses what seems to be primarily an audience in the West, a lot can be taken from his engagement throughout the book with what he describes as the "Modern Constitution [sic]" that disconnects from time, from the 'other' non-modern, and from nature. Latour attempts to revisit the term and show a non-linear and far more complicated set of relationships with both the past and the other. ${ }^{11}$ Similarly, George Arbid has argued in one of his talks that there are no contradictions between traditional and Modern and that the latter is a continuation and only a part of what constitutes the former. ${ }^{12}$ Essentially both arguments are connected; however, it is interesting to note that Latour is attempting to move away from the concept of the Modern while Arbid attempts to move towards using Modern in lieu of 'traditional'. Perhaps the intersection and juxtaposition of these two discussions, one emerging from Europe 


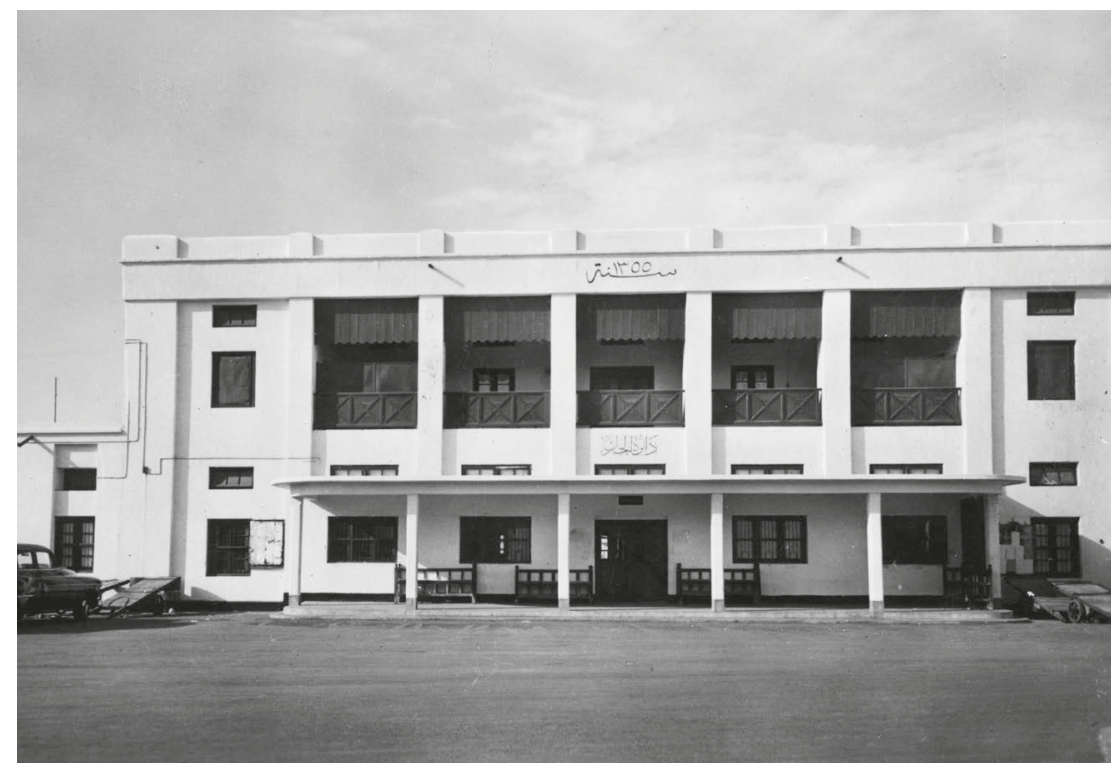

Customs House in the late 1940s (Source: Mary Evans/Pharcide, n.d. Reuse not permitted).

and another emerging from the Arab world, can become an indicator of the hybrid nature of the Modern project and the different forms it has taken in both the built environment and the discourse it is embedded within.

Both Arbid and Latour are critical of temporal borders that demarcate the past. Nonetheless, this paper shall go along with the popular practice among architects of using a date as shorthand for the birth of a Modern project. This chapter claims that Modernity started in Bahrain in the Hijri year of $1355 .{ }^{13}$ These numbers can be found engraved within the embrace of the gracious flow of the word sanat (year) in Thuluth Arabic calligraphy on the south façade of the Customs House, as seen in old black and white images of the building. It is considered to have housed the first department organized by the government, communicating a start of institutionalization and regulatory processes within the Modern nation. The architects working at Bahrain Authority for Culture and Antiquities (BACA), Alaa Al-Habashi and Marwa Nabeel, involved in the conservation of the building refer to the numbers always with excitement, in a more abstract form as "the inscription". ${ }^{14}$ The calligraphy was concealed for years, buried under a thick layer of plaster, and clad with a steel and concrete façade that covered both the year and name of the building one floor below, Daerat Aljamarik. ${ }^{15}$ The name of the building literally fig.2 translates to 'the circle of customs', meaning customs services. 


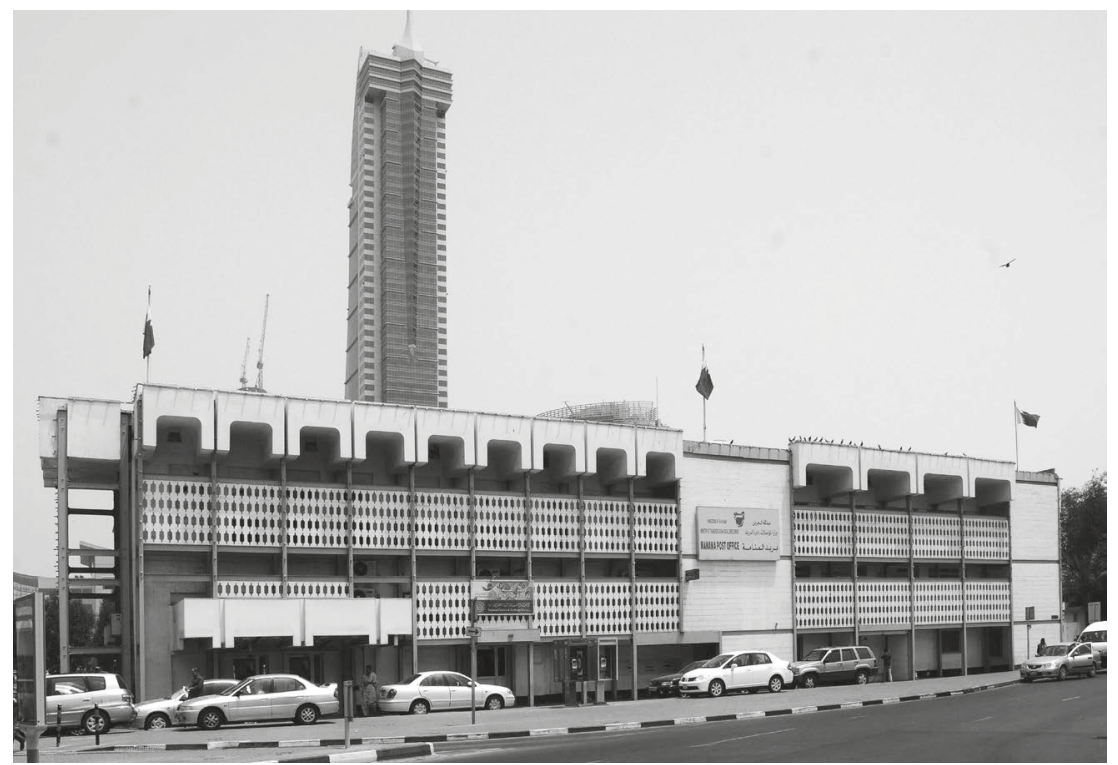

fig.3

Customs House after the 1970s conversion to a post office (Source: Bahrain Authority for Culture and Antiquities, n.d. Reuse not permitted).

Contrary to what would typically be expected when encountering an 'inscription' with numbers and text, it would not be the text that would be difficult to decipher, comprehend, and translate but rather the numbers. The year was written in the Hijri, or Islamic, calendar, and at first the year was converted to the corresponding Gregorian year taking into account only the start of the year, the first day of the first month of 1355; as a result, the corresponding year was 1936. Initially, the author did not take note of the effects of variations in days and months that would affect the conversion of the year, which resulted in some confusion to be clarified below.

Various historians who have frequented the Bahrain Historical and Archaeological Society asserted in May 2019 that the inscription was added years after the building was inaugurated. ${ }^{16}$ There was an agreement, it seemed, among these historians that the building was built before the 1930s; as a result, what had occurred in 1355 and why it was important to document that year on a building façade facing the market of Manama remained a mystery. The interest in the year was motivated firstly by its being covered for so many years and secondly by the belief that it was added to the building years after the first inauguration of the Customs House. Therefore, the year 1936 became important to investigate - to consider important historical events. In search of material evidence of history within the built environment, what can be more obvious than a muted scream of a building: 
"I am 1936". The following study, therefore, departs from the knowledge provided by historians encountered at the Bahrain Historical and Archaeological Society and conservation architects at BACA with the aim of demystifying the importance of engraving the year 1355 on a building.

As has been common among researchers of Bahrain's history, Belgrave's diaries were consulted in search of a significant event in 1936; however, nothing beyond the ordinary in the grand scheme of things stands out. The author remembered that a year was missing in the diary entries, and the description of the diaries was consulted to confirm whether the year corresponded with 1936. The description of the Belgrave papers reads, "They date from 1926-1957 (with a gap for 1937)". ${ }^{17}$ The author then noted that, although the conversion of the year was correct, it was inaccurate. The Hijri and Gregorian calendars do not start and end on the same dates - the beginning of the former does not necessarily coincide with the end of the latter. On converting the last date of the Hijri year, it became clear that those numbers could also refer to the year 1937, and whatever event had encouraged such inscription could have taken place anywhere between Tuesday, March 24, 1936, and Friday, March 12, 1937, to be precise. Whatever the celebration of the engraving of these numbers was, it would soon be deemed unimportant and plastered. It is completely erased from the building's façade, echoing the obscured diary entries in the Belgrave papers. The occluded history, held within these numbers referring to a temporality and engraved on a façade, leads the way to an exploration of the milieu in which the Custom House emerged as a Modern building. ${ }^{18}$ The complex milieu in which Modern buildings manifest on the landscape is far more important than the single designer credited with the work. ${ }^{19}$ It is from here that we proceed to understanding the complex apparatus through which the Customs House has been produced and reproduced over time.

\section{The Customs House: $1440^{20}$}

The building today embodies, within the rehabilitation intervention, the dichotomy of old and new, modern and perhaps avant-garde, preservation and progress. The story behind this recent renovation is embedded in a remarkable contemporary design and cultural scene in Bahrain. ${ }^{21}$ The building was brought to the attention of Alaa Al-Habashi, the conservation consultant at BACA through his intermingling with historians at lectures in various venues outside his workplace. He began researching the building with a junior architect at BACA, Marwa Nabeel, and they were both ready to work on the project officially when BACA made a decision to intervene in Manama, continuing the organization's ongoing efforts to preserve heritage and culture. BACA's long term plan is to register Manama as a UNESCO World Heritage Site, 


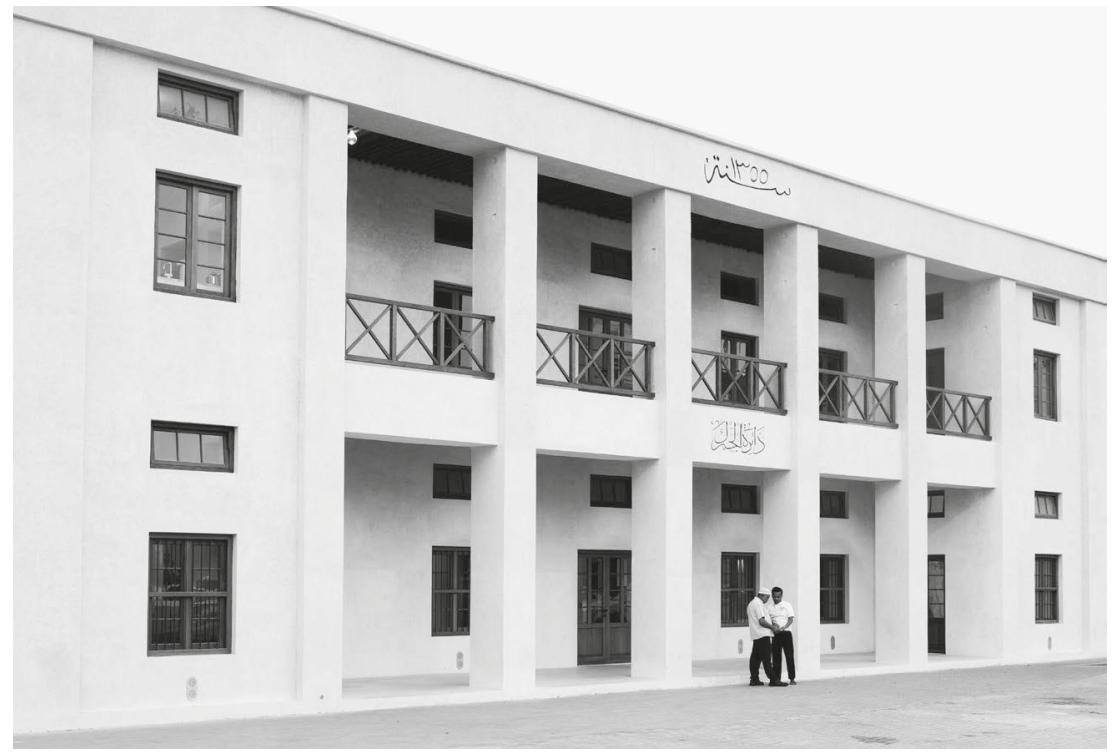

fig.4 Customs House, 2019 (Photo: Khalid Al-Jabri. Reuse not permitted).

and it is currently on the Tentative List under the title, "Manama, City of Trade, Multiculturalism and Religious Coexistence". ${ }^{22}$ Alaa and Marwa encountered historical images with 'the inscription' while conducting their research, and they noted that the original looked entirely different from the existing building. At the time of their investigation, the building served as the Manama Post Office and no longer as the Customs House. The façades were entirely covered, and it was impossible to recognize the original building's features. Therefore, the process of conservation started with an fig.5 archaeological excavation, in search of a buried Modern moment of heritage in Bahrain's history as seen in the images. ${ }^{23}$ This was achieved through the careful removal of the steel and concrete façade of the building built in the 1980s to expose a hidden layer of the original building. Furthermore, material that was added over the years in the interior of the building was also removed to expose the hidden wood ceilings and a chimney among other things. ${ }^{24}$ An architecture studio, Studio Anne Holtrop, was commissioned to carry out the rehabilitation of the building; the office is known for its signature designs and interventions in heritage buildings. ${ }^{25}$

The studio's intervention model in historic buildings, first implemented in the Pearling Path in Muharraq, was adapted for the design of the new extension of the Customs House in Manama. These interventions digress profoundly from the original building and stand in strong contrast with original heritage buildings, rightfully gaining the term new architecture. The term new architecture 

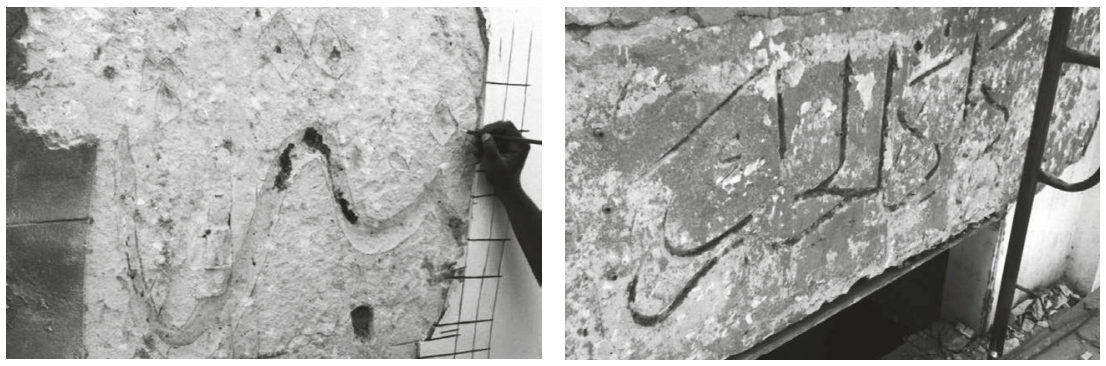

The inscription revealed on Customs House's façade during rehabilitation works (Source: Bahrain Authority for Culture and Antiquities, n.d. Reuse not permitted).

is the term deployed within BACA to differentiate between the more subtle interventions that blend in and those that create a visual rupture within the historic fabric. Therefore, the new intervention by Studio Anne Holtrop in the Customs House is an additional twist, literally and figuratively, to the building excavated by BACA. $\boldsymbol{\Delta}$ It is in the form of an extension that extrudes from the ground, wrapping the building on the west side as it twists and p.19 encircles the roof. It displaces a small building, now demolished, that had been added as a concrete extension to the Customs House in the 1970 s or 1980 s. There seemed to be a consensus between both Al-Habashi and Holtrop that it was the right decision to demolish the extension as there was nothing interesting within it to preserve ${ }^{26}$ However, Al-Habashi did show some regret in regard to not keeping a small part of what was removed, as it was important to maintain, according to him, a reading of history through its different layers - beautiful or not. He stated that he would have done things slightly differently if he could go back, for instance exposing the different layers of the building throughout the years, including the 1970s and 1980s "vicious interventions". ${ }^{27}$ The decisions and paths taken in conserving and rehabilitating the Customs House contribute to an emerging debate among architects in the country about conservation practices and around the value of what is being lost through these practices. This can be witnessed also in the Pearling Path in Muharraq, where diverging approaches are being adopted in its two North and South Sections. ${ }^{28}$ Conservation in the South Section of the trail is subtle and blends in with the old fabric while in the north it is evident and stands in contrast from the environs. Studio Anne Holtrop is leading the North Section of the project, and the executed design for the Customs House is aligned with the studio's approach.

The removal of the latest additional layers of the Customs House to uncover the original building - yet demolishing part of it to make space for a contemporary layer - provides a rich example of the range of aesthetic choices. Furthermore, some architects 
appreciated the design of the Customs House in its later years as the Manama Post Office, as they have always known it, with the façade that covered the original building. The ongoing work and diverse opinions around it have activated concepts among architects and historians related to authenticity, conservation, rehabilitation, and heritage. This created a dialogue, though still young in its formation, to emerge within Bahrain in relation to practices of conservation that one can argue are heavily inherited from global organizations. ${ }^{29}$ Neither of the architects involved knew of the historical significance of the building aside from its being a customs house later converted to a post office. Al-Habashi stated that an interpreter is usually brought in after the project is conserved to interpret the history based on the historical resources provided by BACA. This process of content creation was initially supposed to go hand in hand with the conservation project; however, this became a challenge as the priority of BACA, which is leading this project, was to intervene to prevent demolition of the building..$^{30}$ The architects were able to provide a detailed account of their interventions; however, no research was carried out utilizing the historical documents related to the building. Archives, specifically those of the British Library, that contained information on the building which could have facilitated conservation, were not consulted.

\section{The year 1355}

As a result of the information provided by the conservation architects at BACA and the historians encountered at the Bahrain Historical and Archaeological Society, namely, that the year 1355 was added on at a later date, a survey was conducted on the important events that took place around that year, which is coincidently also missing from Charles Belgrave's diaries. It seems that the most important event, according to the consulted sources and to the writings of various historians, is the introduction of the Nationality and Property Laws in 1937. This was partially fuelled by a rise of nationalism during the 1920s and partially due to the regulations of compulsory property registration. The National and Property Laws of 1937 came as a response from the administration of Bahrain to what was considered the 'growing Iranian problem', which relates to the many property owners considered Iranian subjects in Tehran. A citizenship law was introduced that restricted property ownership to Bahraini nationals, and as a result many Persians had to become Bahrainis to maintain their properties. ${ }^{31}$ This new law created a disruption to the previous pattern of immigration, movement, and transnational connection - a rupture in the social fabric, forging new relations within society and constructing a new form of connection with the land. While these borders were being drawn between Bahrain and Iran by both governments, Bahraini-British relations were thriving. 
In the same year, the ruler Shaikh Hamad bin Isa Al-Khalifa visited Britain to meet King Edward VIII, and the event was highly publicized in the British media. ${ }^{32}$ Meanwhile in Bahrain, the Municipality of Manama was draped with British flags to celebrate the coronation of King George VI in 1937. ${ }^{33}$ These two events are precedents of shifting networks and new emerging relations facilitated by the British, no longer bound by geography. A global network emerged, made possible by the Modern infrastructure of communication and transportation. The development of the Customs House enabled an expansion of processes of importation and exportation.

Many developments occurred in the built environment during that year. A policy was introduced in 1937 related to 'morality zoning'; it moved prostitutes, who were part of Manama's overseas economy, from around the city, specifically the harbour and market, and relocated them to an area to west of the outskirts of the inner city called Grandol. The area became a red-light district regulated by systematic health checks. ${ }^{34}$ Meanwhile, the ruler attempted to modernize the open market and was able to transform it from a space used by street agriculture vendors to a commercial complex with a regulated system of rent collection. ${ }^{35}$ Outside of Manama, and close to the first oil well, the American company BAPCO had completed the first oil town in the Gulf: a gated community isolated by a different architectural language and physically by a wall from the rest of the country. ${ }^{36}$ Furthermore, the first ban was issued on the construction of huts along the main routes. In the following years and by the initiative of Belgrave and other British political agents, the ban was extended to other areas being prepared for a Modernization project as they were designated to host the public institutions of the country. ${ }^{37}$ In the administrative report prepared by Belgrave after his first ten years in Bahrain, he states that the country had changed drastically since his arrival:

Changes are taking place all over the Gulf, but of the Arab States, Bahrain is changing most rapidly. The most conspicuous visible changes in comparing Bahrain to-day and ten years ago are in the capital, where a person returning to the country would notice the wider streets, better buildings, and a decrease in straw huts, trees, gardens and more vegetation, large shops selling European goods, motor traffic, European dress worn by natives, increasing use of machinery, partly owing to the installation of electric power, knowledge of English language, and a far greater interest taken in outside world affairs. ${ }^{38}$

The year 1355 seems to be significant; however, any event occurring within it is the accumulation of previous events, in addition to the report being submitted in 1937, making it likely that these affairs could have taken place during the preceding years. It is vital here to note that the available information does not shed 
light on why Charles Belgrave's entries from that year were missing or why the calligraphy on the Customs House was covered - or if either was a deliberate act of erasure. According to BACA's technical report of the building, "The traditional plaster used was strong enough to survive". ${ }^{39}$ However, it is possible that the first layer of plaster, which was most likely a mixture of lime, gypsum, and other additives, had worn due to humidity and therefore was covered. Fragility of material has always posed challenges to conservation practices in the Gulf.40

\section{The Customs House: 1355}

John Gordon Lorimer, a British historian and diplomat who authored an encyclopaedia about the Gulf, documented in the 1860s the regulatory processes in Bahrain when customs collecting duties were delegated to Hindu merchants by the ruler. The process seemed to have upset all involved parties, including the ruler himself, who did not profit from this arrangement. ${ }^{41}$ According to Belgrave, however, the first regular centralized customs department in Bahrain was established in 1923 by a public servant of the Indian government who based it on the Indian Methods and Bill of Entry System. In the following year, Mr. C.L. DeGrenier was appointed as customs director. On its initiation, the department would serve as a regulatory body for customs revenues as well as for the collection of pearling, boat licenses, and registration of craft evolving into a point of entry for foreign individuals. ${ }^{42}$ According to a government report prepared by Charles Belgrave, the public encouraged regulating these processes as this shifted the authority from individuals to institutions. ${ }^{43}$ By 1937, the Customs House personnel consisted of the formerly mentioned director in addition to nine senior and experienced Indian clerks, a dozen local clerks, and 25 naturs ${ }^{44}$ - an organizational model that could be argued to be roughly still in place to this day, especially in the Bahraini private sector. The significant size of it was due to the position of Bahrain in the trade routes of the British Line Steam Navigation, Hansa Line Steamer, Yamashita Line, Mitsui Line, and occasionally the Strick Line Steamer. ${ }^{45}$ Therefore, the Customs House revenues were partly collected from the transit of goods, including to mainland Saudi Arabia.

The Customs House was in fact, contrary to the urban myth about the date of its construction, completed and inaugurated in 1355 as can be found in different sources. The inscription therefore simply communicates the date in which the building was built, whether it was added at the opening or after. There is a possibility that the confusion of the date is from one of the most widely circulated books, Bahrain in Original Photographs, 1880-1961, in which the inauguration of the building is attributed to the early 1930 s. ${ }^{46}$ Furthermore, in relation to Charles Belgrave's diaries, the entries of 1937 were not missing or expunged; rather, 
they were not available according to James Downs, the Middle East Collections Project archivist at the Special Collections at Exeter University. ${ }^{47}$

The first building was assigned to the Customs House in 1917, following the building of Manama Port in $1912 .^{48}$ The pier sheds were built in 1924; a trolley line system was added in 1925 to facilitate and accelerate the removal of cargo; and small docks were constructed in 1927 alongside a small harbour mole. In 1937, the mole was widened with the addition of the Customs House building, located on the site of the docks. The site of the building was built on reclaimed land that provided additional space for storing cargo. Further services were developed to serve the port, such as improvements to lighting in 1931, enabling work to continue during the night. Belgrave had also proposed future plans for the Customs House, which entailed the expansion of the pier into deeper waters to enable larger boats to come into the port during times of low tide. ${ }^{49}$ The building itself contained "light, airy" offices on the ground floor and a flat on the first floor, with the northern façade facing the waterfront and the southern towards the market. ${ }^{50}$ And between the building and the market was a square, called by Belgrave at the time the customs square, that had a round garden with a fountain in the centre. The roundabout, or "circle garden" as Belgrave called it, was used to control the flow and direction of traffic as the use of cars had increased within that neighbourhood..$^{51}$ The garden was added to beautify the area - one of the occupations of Belgrave was to create more green spaces in Bahrain. ${ }^{52}$ The building is what would typically be referred to as colonial architecture although it was built using the cross-pollination of building techniques between Bahrain, Iran, and India, facilitated by pre-existing trade routes developed further by the British. The use of 'colonial' to describe the buildings could be attributed to three explanations: size, programme, and the relations between the inhabitants of the country and the British. The building was larger than the older fabric of the city. In a photo taken of Manama in 1936, the proliferation of administrative buildings that disrupt the intricate urban fabric is evident. ${ }^{53}$ Though, it is not possible to state if the Customs House was one of the buildings that appears in this image in particular. The second connection to colonial buildings is through programme: what the building represents rather than its architecture. It was an institutionalization of processes that align with those of British institutions. ${ }^{54}$ The third explanation for it being perceived as a colonial building pertains to the British presence within the country, considered a colonial presence. Therefore, any building used by the British was considered a representation of colonization. For example, 1956 protests in Bahrain in solidarity with Egypt against the British targeted buildings occupied by the British, either through assembly of protesters around or direct attacks on the buildings. ${ }^{55}$ 


\section{5 as a decisive [modern] moment}

The disappearance of spaces from the cityscape, their resurrection, new-found value after the passage of time, and confinement to the drawing board and in spaces of archives raise questions about what these spaces represent in the historical narrative of a country, exposing a duality occasionally and many times a multiplicity of history. The resurrected 'inscription', or the year 1355 , can indeed be used as a shorthand for various issues related to Modernity, or a Modern moment. Foremost is the widespread knowledge as to when the building was first built, and the multiple confirmations regarding the inscription being added after years of its inauguration in the 1920s or early 1930s. The void of archives and documentation enables an oral practice of knowledge exchange and rumours, that with repetition leads to the circulation of unquestionable facts. This could relate to a loss in translation, inaccessible documents, and citations of the same popular sources for history. In the case of Manama, and specifically the era till its independence in 1971, there is an abundance of documents that can be used to verify information; however, this is not always the case. These documents along with oral history can enable more comprehensive historical narratives to emerge and can forge new connections between the various events that constitute the production of a building. Furthermore, it is clear that the notion of a Modern moment, or the beginning of regulatory processes within society and of modernization, was not a product of an event; in fact, there are precedents, and they change according to the story of progress being told. For example, the description of the town of Manama differs between being a Modern metropolitan town in Lorimer's gazetteer in the 1860s and being deemed backwards when Belgrave arrived in the 1920s in Bell's description in Life magazine. ${ }^{56}$ The latter inflated the agency of Belgrave in developing the country, which is challenged by new research. ${ }^{57}$

Bahrain, and the Gulf in which it is located, have yet to reconcile with intertwining Modern and colonial heritages. Perhaps it is worth asking, what does this mean when attempting to (re)search (for) narratives of Modern heritage in societies where facts are subject to the prevalence of vulnerability on different levels? Vulnerabilities related to facts, accessibility of archives, translations, narratives of history, and obscured spaces within the city. "Can the Subaltern [spaces in our city] Speak?"58 and does it matter if they do? 


\section{Notes}

1 See Ahmed Kanna, Amélie Le Renard, and Neha Vora, Beyond Exception: New Interpretations of the Arabian Peninsula (Ithaca: Cornell University Press, 2020); Harvey Molotch and Davide Ponzini, The New Arab Urban: Gulf Cities of Wealth, Ambition, and Distress (New York: New York University Press, 2019).

2 Murray Fraser and Nasser Golzari, Architecture and Globalisation in the Persian Gulf Region (Abingdon: Routledge, 2016). 3 See Nelida Fuccaro, Histories of City and State in the Persian Gulf: Manama since 1800, Issue 30 of Cambridge Middle East Studies (Cambridge: Cambridge University Press, 2009); Pascal Menoret, Joyriding in Riyadh: Oil, Urbanism, and Road Revolt, Vol. 45 of Cambridge Middle East Studies (Cambridge: Cambridge University Press, 2014); and Farah Al-Nakib, Kuwait Transformed: A History of Oil and Urban Life (Redwood City: Stanford University Press, 2016).

4 Farah Al-Nakib. Kuwait Transformed, 16.

5 Rosie Bsheer, Archive Wars: The Politics of History in Saudi Arabia (Redwood City: Stanford University Press, 2020).

6 Sultan Sooud Al-Qassemi and Roberto Fabbri, "Re-Engaging with the Gulf Modernist City: Heritage and Repurposing Practices", (call for 10th Annual Gulf Research Meeting, Gulf Research Centre, Cambridge, UK, July 2019).

7 See Fernand Braudel, On History (Chicago: University of Chicago Press, 1982), 25-54.

8 Ann Laura Stoler, "A Recursive Mode: Concept-Work for Colonial Histories", talk at Boğaziçi Üniversitesi, Istanbul, Turkey, May 10, 2013, accessed October 26, 2020, https://youtu.be/kj_OTbSsoKM.

9 James Onley, "Britain's Informal Empire in the Gulf", Journal of Social Affairs 22, no. 87 (2005): 29-45.

10 Charles Dalrymple-Belgrave, Papers of Charles Dalrymple-Belgrave, 1926-1957, March 31, 1926, (Special Collections, University of Exeter), 3; James Bell, "He Said Forward to the Backward!", Life, November 17, 1952: 157-158.

11 Bruno Latour, We Have Never Been Modern (Cambridge, MA: Harvard University Press, 2012), 10-15.

12 George Arbid, "The Identity Trap by George Arbid | Executing Culture Shock | Nuqat 2013", accessed October 26, 2020, https://www.youtube.com/watch? $\mathrm{v}=0 \mathrm{Ffz}$ UXI_BX4. Arbid states, "Of how we could look at history of architecture. Because I argue that what we call tradition today is actually centuries of modernisms compiled across time. So, it is absolutely wrong to take tradition as something that came to us, that is a given. It is actually something that has been transformed. And if we look at modernism today as one of those stages then we do not see the contradiction between learning from tradition and being modern".

13 The year according to the Hijri calendar. Throughout the text, there is a mediation between the Hiji and Georgian calendar. The use of a year as a shorthand for major events follows Bruno Latour's use of the year 1989 in his book We Have Never Been Modern as a shorthand for major world events, both the victory of capitalism with the fall of the Berlin Wall and the start of its decline with the first Paris Conference on the global state of the planet.

14 These observations are based on semi-structured interviews conducted in 2018 and 2019 by the author with Alaa Al-Habashi, a former conservation consultant at Bahrain Authority for Culture and Antiquities (BACA), currently practicing and teaching in Egypt, and Marwa Nabeel, a junior architect in BACA, who worked under Alaa.

15 Marwa Nabeel, Conservation \& Rehabilitation Project - Phase 1 Summary Report (BACA: Bahrain, 2014), 2-4.

16 The Bahrain Historical and Archaeological Society organizes a series of lectures bringing together a community interested in history. The discussion with the historians about the date of this building specifically occurred on May 15 , 2019, a year after a lecture by Nader Kadhim, researcher and author of the book La ahad yanam fi al Manama (No One Sleeps in Manama). 17 "Record: EUL MS 148 - Papers of Charles Dalrymple-Belgrave Relating to Bahrain", University of Exeter, The Bill Douglas Cinema Museum, and Falmouth University archive catalogue, accessed October 26, 2020, http://lib-archives.ex. ac.uk/Record.aspx?src $=$ CalmView. Catalog\&id=EUL+MS+148\&pos $=5$. 18 Ines Weizman has conducted a similar investigation on customs houses found in the Golan. In her work, she does a forensic analysis of the building material to understand transnational processes. Ines Weizman, "Bauhaus Modernism across the Sykes-Picot Line", in Dust and Data, ed. Ines Weizman, 544-572. 19 Adrian Forty states, "History of architecture and design is full of attempts to make sense of buildings and objects through careers, ideas and theories of known designers, and their approach is to be found even in works that are not specifically biographies". Forty, Objects of Desire: Design and Society since 1750 (New York: Pantheon Books, 1995), 239. 
20 The Hijri year corresponding with the date this paper was written.

21 Alaa Al-Habashi, Skype interview with author, May 21, 2019; Marwa Nabeel, interview with author, Manama, 2019; Anne Holtrop, interview with author, Muharraq, August 22, 2018.

22 UNESCO World Heritage Convention Tentative List, "Manama, City of Trade, Multiculturalism and Religious Coexistence", accessed November 24, 2020, https://whc.unesco.org/en/ tentativelists $/ 6354$.

23 Al-Habashi, interview; Nabeel, interview.

24 Nabeel, Conservation \& Rehabilitation Project - Phase 1 Summary Report, 4.

25 See the work of Studio Anne Holtrop in the Pearling Path in Muharraq, a UNESCO World Heritage Site registered as a "Pearling, Testimony of an Island Economy". It consists of 17 buildings in Muharraq City and three offshore oyster beds. There are ongoing efforts to register Manama as a "City of Trade, Multiculturalism and Religious Coexistence".

26 Al-Habashi, interview; Holtrop, interview.

27 Al-Habashi, interview.

28 Lucia Gomez-Robles, site director for the South Section of the Pearling Trail, interview with author, Manama, September 11, 2018.

29 Anas Alomaim mentions the role of invited international agencies, such as the World Bank Group, United Nations, and International Council of Museums, in releasing countries of their colonial trauma through education, Modernization, and culture. Yet universal values are pursued within this decolonizing process that is implemented by these organizations as opposed to allowing them to develop naturally from the context. Anas Alomaim, "Nation Building in Kuwait 1961-1991", (PhD diss., UCLA, 2016), 2-25.

30 Ghassan Chemali, urban conservation consultant at BACA, interview with author, Manama, December 18, 2018.

31 Nelida Fuccaro, "Mapping the Transnational Community", in Transnational Connections and the Arab Gulf, ed. Madawi Al-Rasheed (London: Routledge, 2004), 39-58.

32 Bahrain Ruling Family's Desire to Visit Other States, File 19/209 I (C 73), British Library (BL), India Office Records and Private Papers (IOR), IOR/R/15/1/363, in Qatar Digital Library, accessed October 26, 2020, https://www.qdl.qa/en/ archive/81055/vdc_100000000193. 0x000150.

33 Fuccaro, Histories of City and State in the Persian Gulf, 121-122.
34 Elham Fakhro, "Belgrave's Quest for Moral Order in Bahrain, 1926-1957" (PhD diss., University of Oxford, 2018), 253-259. 35 Government of Bahrain Administration Report for 1926-1937 and Annual Reports for 1937-1944, BL, IOR, IOR/R/15/1/750, in Qatar Digital Library, accessed October 26, 2020, https://www.qdl.qa/archive/ 81055/vdc_100000000193.0x0002d7. 36 Fuccaro, Histories of City and State in the Persian Gulf, 191.

37 Ibid., 198.

38 Bahrain Administration Report for 1926-1937, IOR/R/15/1/750, in Qatar Digital Library.

39 Nabeel, Conservation \& Rehabilitation Project, 4.

40 See Silvia Mazzetto, "Heritage Restoration as a Tool to Promote Architectural Identity in the Gulf Regions", Preservation, Digital Technology \& Culture 47, no. 1 (2018) 3-11; Marco Motisi et al, "The Bahrain Pearling Path: Urban Planning, Structural Investigation and Design of the Strengthening Interventions", in Structural Analysis of Historical Constructions:

An Interdisciplinary Approach, eds. Rafael Aguilar et al. (Cham: Springer, 2019), 1830-1838.

41 Gazetteer of the Persian Gulf. Vol I. Historical. Part IA \& IB. J G Lorimer. 1915 [928] (1083/1782), BL, IOR, IOR/L/PS/20/ C91/1, in Qatar Digital Library, accessed October 26, 2020, https://www.qdl.qa/ archive/81055/vdc_100023575946. 0x000054.

42 Bahrain Administration Report for 1926-1937, IOR/R/15/1/750, in Qatar Digital Library.

43 Ibid.

44 Natur is an Arabic word that means watchman. In Bahrain, the naturs were under the command of the ruler and would be given weapons; however, they were not instructed in how to use them. They were usually descendants of Baluchi bodyguards and would soon be enrolled in the police force whenever a vacancy arose. 45 Bahrain Administration Report for 1926-1937, IOR/R/15/1/750, in Qatar Digital Library.

46 Andrew Wheatcroft, Bahrain in Original Photographs, 1880-1961 (London: Kegan Paul International, 1988), 80.

47 James Down, email communication, September 18, 2020. Down is Middle East Collections Project archivist at the Special Collections, Exeter University.

48 As per the timeline provided by the Kingdom of Bahrain, Ministry of Interior, Customs Affair's website, accessed in October 26, 2020, http://www. bahraincustoms.gov.bh/history_customs. php?SID=WWxR d2VVcHVUblJRVkZFOQ \%253D\%253D 
49 Bahrain Administration Report for 1926-1937, IOR/R/15/1/750, in Qatar Digital Library.

50 Ibid.

51 Ibid.

52 Doherty Gareth, Paradoxes of Green: Landscapes of a City-State (Berkeley: University of California Press, 2017), 23.

53 Persian Gulf States (excluding Kuwait), Muscat and Oman: towns. 1961 Jan 01 1961 Dec 31. DEFE 60/172, Arabian Gulf Digital Archive, accessed October 26, 2020, https://www.agda.ae/en/catalogue/ tna/defe/60/172.

54 See Peter Williams, Technical Assistance: A Factual Survey of Britain's Aid to Overseas Development through Technical Assistance, Vol. 4 of British Aid (London: The Overseas Development Institute Ltd., 1964); Valentin Seidler, "Institutional Copying in the 20th Century: The Role of 14,000 British Colonial Officers", Journal of Contextual Economics 137, No. 1-2: 93-119.

55 Abd Al-Rahman Al-Bakir, Al-Bahrain ilti al-manfri Sant Hilrinah [From Bahrain to Exile in Saint Helena] (Beirut: Dar Maktabat Al-Hayat, 1965), 122-123.

56 Gazetteer of the Persian Gulf, IOR/L/ PS/20/C91/1, in Qatar Digital Library; Bell, "He Said Forward".

57 See Omar H. Al-Shehabi, Contested Modernity: Sectarianism, Nationalism, and Colonialism in Bahrain (London: Oneworld Academic, 2019).

58 The question is inspired by Gayatri Chakravorty Spivak's work that questions if a subaltern can speak when it is weighed down by the load of imperial, past and present, conditions. Spivak, "Can the Subaltern Speak?" in Can the Subaltern Speak?: Reflections on the History of an Idea, ed. Rosalind Morris (New York: Columbia University Press, 2010), 237-292. 